\title{
Among Cultures
}

The Challenge of Communication

\section{Edited by Bradford J. Hall, Patricia O. Covarrubias and Kristin A. Kirschbaum}

First published 2002

ISBN 13:978-1-138-65781-6 (hbk)

ISBN 13:978-1-138-65782-3 (pbk)

ISBN 13:978-1-315-62117-3 (ebk)

\section{Chapter 7}

\section{Why Do So Many People Get Treated Poorly?}

Bradford J. Hall, Patricia O. Covarrubias and Kristin A. Kirschbaum 


\section{Chapter 7}

\section{Why Do So Many People Get Treated Poorly?}

Vanessa's brother had called that morning from California. After visiting about family, school, and her plans after graduation, he asked her if she had heard on the news about the cops beating some illegal aliens the other day.

"Yeah, it reminds me of those cops from the recent shooting."

"Those cops in California are so racist they just beat the snot out of anybody they don't like."

"Well, I guess you guys over there have plenty of wetbacks for them to beat," she said. Then, trying to lighten things up, she joked, "Lucky you didn't get mistaken for one, playing all that 'beanerball' like all the other wetbacks."

Her brother laughed softly. He didn't really like being associated with the term wetback and changed the topic.

"So how did it go at the used car place? Did you get a fair trade on your old car?"

"Well, the guy tried to Jew me down, but I held firm and I think it worked out okay."

"It doesn't surprise me, sis. Most women don't have a head for business, but you always were quite the Indian trader when we were young."

"Hey now, who wanted to be the lawyer of the family?" Vanessa laughed.

After a little more joking, the conversation ended and Vanessa turned to her computer. She usually went online around this time of day before she had to go to work. Today she was feeling quite excited about it. She had spent the last four days talking online with a guy named Adrian who she had learned was attending another university about two hours away. She had been in a chatroom when all of a sudden she had gotten an instant message from some guy named Adrian. She had hesitated at first, but she replied and they had 


\section{(continued)}

had a great visit. He had found her accidentally because he had just sent out a general message of " $h i$ " to anyone logged in on a university account at her university. Since then, they had talked every day and things had gotten better every day. He was funny and talking with him seemed to make her whole day go better. She had been a bit worried about the contact and hadn't given out much information about herself, but she had been relieved when she had made some calls and found out he was a real student where he said he was. She hoped he wasn't just some dumb jock, though.

She was in luck-he was also online and soon they were visiting as usual. Later in the conversation she mentioned that she was Catholic and would be going to Mass that weekend. He wrote back and said his parents were devout Hindu, but he really wasn't into religion.

"Hindu?" she thought and asked a few more probing questions. It turned out that his parents were first-generation immigrants from India.

"India?" she had wondered aloud. "Isn't that somewhere over by Japan or was it Saudi Arabia?" This didn't sound so good. She continued to think about what she knew of people from India. "Hmmm, they don't eat cows, they are small in stature, they talk funny like that convenience store clerk on the 'Simpsons' and they're terribly sexist. After all, their women always have to be covered in robes and veils. Weird."

About then she noticed that he was asking about maybe getting together sometime to meet. A few moments ago that would have sounded exciting

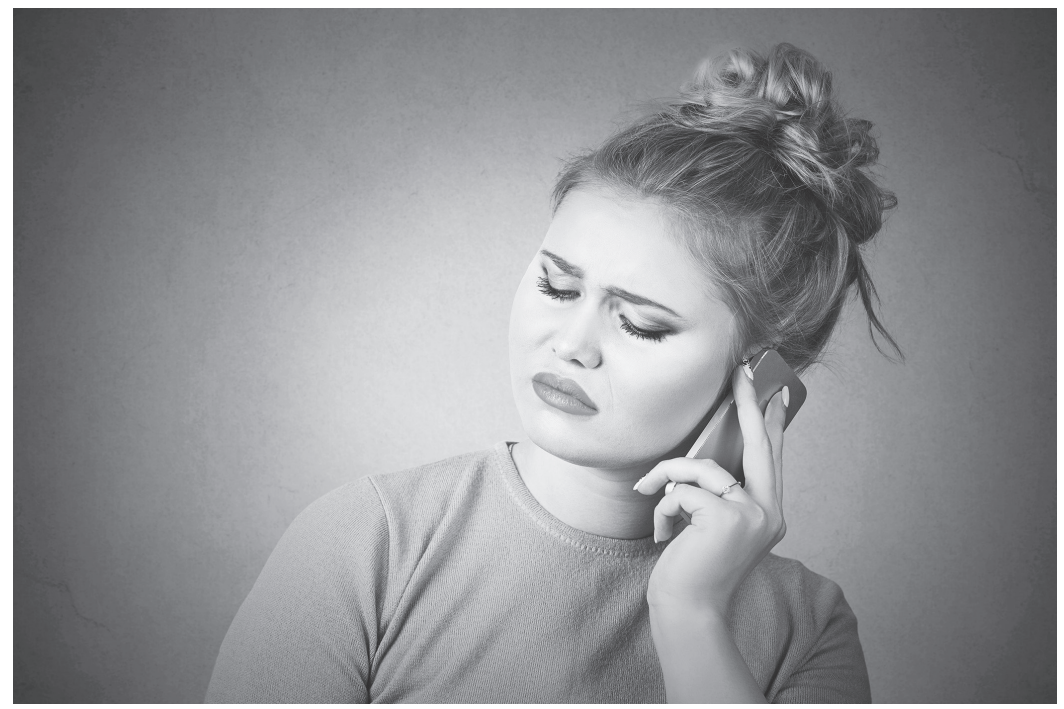

FIGURE 7.1 
and a bit romantic, but with an "Indian"? All of a sudden her interest just seeped away.

"No, I don't think that is a good idea," she said. "I don't believe in relationships that get started online." She felt a bit guilty, but she knew she wouldn't be having any more chats with Adrian.

Soon it was time for Vanessa to head out to work. She hopped in her car and headed to the mall where she worked in a clothing store. As she drove by the museum downtown she noticed what seemed like a hundred little Japanese guys streaming out of the door. She groaned silently.

"They are everywhere," she thought.

It reminded her of the trip she and two of her friends had saved for and finally took to Australia two summers ago. They were tight on money and had stayed in hostels. Unfortunately, so had countless groups of Japanese. They had tried to be nice about it at first, but the Japanese were just impossible. They were loud and pushy and always seemed to be up too early and noisy at night, and she had thought Japanese were supposed to be quiet and polite. She and her friends had not been able to get away from them. There was always another group everywhere they went.

Vanessa paused in her remembrances as she came to a stoplight and noticed an old homeless guy sitting over on the sidewalk. Carefully, so as not to look obvious, she reached over and locked her other car door. You just never knew with people like that.

Walking into the mall, she passed a group of guys wearing baggy jeans. She didn't look over at them. She knew their type and didn't want any problems. She'd had a friend back in high school that had gotten beaten up by guys like this.

"Jerks, I wish they'd get a real job instead of hanging around here, but I guess they've got all the money they want from selling coke to the little kids from their neighborhood. Why get a real job?"

Vanessa was relieved to get into work. She smiled and waved at John, one of her coworkers. After clocking in, she ran into Tiffany, her section manager. Vanessa forced herself to be nice. Tiffany was a real ditz, a typical blonde, and she hated having her as a supervisor. She still couldn't believe that Tiffany had gotten the promotion over her; she had been there as long as Tiffany and wasn't nearly as dense. But Tiffany just had to wiggle her little blonde head and Matt, the store's main manager, was at her beck and call.

"Men! They're all alike."

Her thoughts were disturbed by an announcement over the store intercom.

"Call on line four," the voice said.

She hated that. It was the store's new code meaning that someone black had entered the store and all the sales staff were to be particularly watchful for shoplifting. It had seemed so prejudiced to her when the policy had been 


\section{(continued)}

explained to her and she really wasn't that sort of person. But it did seem that they had a lot of problems with black people shoplifting and some of them just couldn't be trusted. She'd had this black woman in the other day claiming she'd bought something here and wanting a full refund, and when she had tried to explain that they didn't even carry that item in the store, the woman had started yelling about her rights and Vanessa being prejudiced. It had been so embarrassing. If these people didn't want a bad reputation, then they should act decently.

It reminded her of her last job as a waitress. All the waitresses had a code for when Native Americans came in. They were such awful tippers no one wanted to serve them. No wonder they didn't always get the best of service. Vanessa sighed. It was going to be another one of those days.

Because there are well over a dozen instances of stereotyping, ethnocentrism, or prejudice in this story about Vanessa it may seem unrealistic. However, these types of things and many more are going on in the world every single day. This opening story combines many different, but real, incidents and thoughts that students have told us about over the years. Sometimes students have heard so many lectures about the evils of prejudice that they tune out, yet stereotyping, ethnocentrism, and prejudice are still some of the major obstacles in intercultural relations, and it is important that we better understand how and why these creep into our daily lives. These are real challenges that can be found all around us. We have done some research in this area and these sorts of problems seem to be found everywhere there are groups of people. It is not just a problem for groups that have come to have a reputation for being prejudiced. Individuals from any background or group can develop prejudice toward other groups, even toward groups they believe are prejudiced toward them. It is so often a vicious circle of blame and justification.

Although the United States has had more than its share of problems with these challenges to getting along, they can be found throughout the world. Sometimes we are told that a particular country, such as Morocco, Switzerland, Japan, Panama, and others, doesn't really have prejudice like they do in the United States. Invariably we will later, through observation, reading, and especially talking with other people from that particular place, learn that, in fact, they do have such problems there and that those making the claims have either lived a very sheltered life or have become so used to the particular prejudices afflicting their part of the world that they fail to see them. Usually they do not belong to a group that is typically a target for prejudice in that community, so it may be easy for them to miss the problems. The groups targeted may be different, but these are worldwide problems. 
We will discuss each of these particular challenges - stereotypes, ethnocentrism, and prejudice - in some detail. Hopefully, as you read this chapter, you will think about how these issues may be affecting your own life and not just focus on "others" who have the "real" problem with this and how much you wish they could read this chapter.

\section{STEREOTYPES}

Stereotypes are attributions that cover up individual differences and ascribe certain characteristics to an entire group of people. Some writers treat stereotyping as simply a less severe version of prejudice. As such, stereotypes are often seen as the forerunners of prejudice and, when our stereotypes become strong enough, they turn into prejudice. Although we recognize a certain logic in this thinking, we believe it confuses distinctions between stereotypes and prejudice in ways that lose some of the value that each concept has for helping us to understand and deal with the world in which we live. These distinctions will become clearer as we discuss prejudice and another related concept, ethnocentrism. However, we want to lay the foundation for this distinction by first considering the very roots of stereotyping: categorization and the human desire to understand and make sense of the world around us.

\section{Categorization}

When we categorize the world around us, what are we doing? We are putting things together that are perceived to match in some way and simultaneously separating those things from other concepts or objects in the world. A category highlights what two or more things have in common in contrast to other things that do not have this commonality. We categorize all the time. We know what cars, rocks, shovels, relatives, poisons, schools, blouses, and musical instruments are. These things are categories that highlight some point or points of similarity that makes the categories recognizable and useful in our efforts to interact with each other. There are many different levels of categorization; therefore, even though we know certain things are musical instruments, we can also recognize that within that category there are such things as wind instruments, percussion instruments, string instruments, and brass instruments. Within each one of these types of instrument categories are further divisions and categories. This sort of layered categorization can be found in virtually everything around us. Our world is a very complex environment, and categorization makes it possible for us to manage and, at least in part, understand it.

Categorization is the fundamental quality of conscious human thought. ${ }^{1} \mathrm{We}$ could not think as we now do without categorizing things. Knowledge would 
be impossible, as there would be no basis for carrying information from one experience to another experience. We can drive a new car without any difficulty because we categorize and know what a key, steering wheel, gas pedal, and so forth are. We don't have to learn it anew each time. Another example is zippers. We know how they work in general and don't have to rediscover how to use a zipper each time we encounter a new one. Examples of this kind are endless. Our language inherently assumes categories. We know what letters are and what are not letters. We know basically what words mean within a particular language and what they do not mean.

We have spent some time emphasizing the basic role of categories and categorization to our human existence, for without this process society could not exist as we now know it. Categories are crucial to all of humanity and that will not change.

Humans have demonstrated a great desire to learn about their world. We want to understand what is going on around us and we do this in part through the use of categories. The knowledge and categories that have been generated by different human communities may in some cases be very different, but every human community has generated knowledge of various types that they use to live every day of their lives.

\section{Fundamental Attribution Error}

Obviously, one of the things we as humans want to understand is other humans. So how do we do this? We categorize what they do based on some perceived similarity. Statements such as those that follow reflect this process:

Women are good listeners.

Men are often aggressive.

Be careful around people who dress like that.

Oh, I get why he was so polite. He's from Japan.

Well, you shouldn't be surprised by that kind of behavior. She's a lawyer.

The minute we categorize people and attribute any behavior, belief, or feeling to that category, we have stereotyped them. We have put them together in a way that focuses on a similarity (real or imagined) and provides an explanation (accurate or inaccurate) for behavior. Simultaneously, we are for that moment masking or ignoring for all practical purposes the differences that exist between the humans placed in that category.

Stereotyping involves an extension of a form of reasoning that has been labeled the fundamental attribution error because it is so common around the world. ${ }^{2}$ The fundamental attribution error may occur when either we or someone else has done something that needs to be explained. This form of 
reasoning is particularly strong when action is perceived as negative or strange. Specifically, if someone else does some questionable act, such as trip, yell in anger, or refuses to share what they have, we tend to attribute that action to that particular person's inner disposition or personality. He or she is seen as clumsy, hotheaded, or stingy. On the other hand, if we do the same thing, we tend to emphasize situational influences. We note that someone moved a skate to a place it shouldn't be so, of course, we tripped; we have had a bad day and our reaction of yelling in anger is really just an expression of frustration about all of those things that have been done to us throughout the day; or we know that we can't give part of what we have away right now because we are saving it for another, more important time. This does not mean that the opposite never occurs. Sometimes we are surprised by someone's actions and blame it on the situation, or at times we fail at something and in turn think of ourselves as losers; however, the general tendency among humans appears to be the process captured by the fundamental attribution error.

The connection between this thought process and stereotyping is made when the other person we are observing is seen as belonging to a different category from us. In this situation people not only feel that the questionable act is a stable part of that person's personality, but associate that type of action with the entire category to which that person is seen as belonging. If we hear a woman say something negative about another person at work, we may silently conclude, "Women are such gossipers, always looking to backstab someone else." If the person who had said the same thing was a man, he would "know" better than to make such an attribution because he is a man. So, instead, he would either take the situation into account or pick another category that he does not share with the other person as a way to explain that behavior, such that he is French, homosexual, or communist. We all belong to many categories, so there are always many from which to choose. In the example of the woman who made the negative comment about a coworker, we might as well have selected some other category, such as Mexican American or secretary, or whatever category of person came to mind in that situation. Which category comes to mind depends in part on the previous stereotypes we have developed. Stereotypes have been shown to have a great impact on what we perceive and what, through the process of avowal and altercasting, we are likely to encourage in others. ${ }^{3}$ Using the example we started with in the previous paragraph, we may have the stereotypes that secretaries gossip, secretaries are women, and women gossip. If it turns out that the person who spoke about others was a woman and a secretary, we would have confirming proof in our own minds that our stereotype was true. Alas, noticing other women secretaries who did not do that would probably not change our stereotype; it may only make us think of those other women as exceptions to the rule. If it turned out that the woman who gossiped was a scientist and we don't typically think of scientists as gossipers, we would probably only connect 
her gender with the gossip. On the other hand, if the person who spoke that way turned out to be a male secretary, we may simply attribute the gossip to his secretary identity. In this way stereotypes tend to reinforce themselves in our minds by predisposing us to expect and look for certain things.

We don't learn all, or even necessarily most, of our stereotypes from personal experience, though. We also learn stereotypes from our family, friends, coworkers, and the mass media. Part of the indirect learning process of stereotypes is similar to what we just described because we tend to assume that the stereotypes we hear from others, particularly when we trust those others, are based on personal experiences, and they are then also given credence. Stereotypes that we learn through others are accepted before we have any personal "proof." However, given the power of stereotypes to attune our way of thinking, we can often find such so-called proof.

\section{Five Points of Variance}

Stereotypes vary along five major dimensions: direction, intensity, specificity, consensus and accuracy. ${ }^{4}$

\section{Direction}

Direction refers to whether the stereotype is positive or negative. Some stereotypes, such as those people are lazy, rude, and dumb, are obviously negative. Others stereotypes, such as those people are hardworking, polite, and smart, appear to be positive. However, when we focus on a rather narrow aspect of any one person, even positive-sounding stereotypes can become negative. Tan laments that the stereotype of Chinese as always very polite gives people the idea that they can't take a strong leadership role. ${ }^{5}$ In the same way, stereotypes of African Americans as athletic may prevent some from seeing the intelligence and hard work that goes into athletic achievements. Or the idea that Japanese are very smart in mathematics may create problems for those who are not. Because stereotypes limit our vision of others, they are always potentially dangerous.

\section{Intensity}

Intensity alludes to how strongly the stereotype is held. Based on various experiences, some stereotypes are held very strongly. Perhaps we learned them when we were young and can think of a number of experiences that support our view of the other group. This often makes it hard to notice or remember the many times when the stereotype did not hold up. It also may result in our treating others such that we encourage them to respond in stereotypical ways. Remember Gong's experience with a colleague who was sure she always ate egg rolls for 
lunch. Her coworker's idea of what Chinese ate made her notice any time this was the case, but not really attend to the fact that it rarely happened. However, other stereotypes are only held loosely. Perhaps we don't have much exposure to the other group or we have seen enough to know that although some things are at times the case, they are often not the case as well. In this way we are aware of the stereotype, but we consciously work at remaining open to variations in each individual case and situation.

\section{Specificity}

Specificity relates to the nature of the stereotype. Does the stereotype concern very broad and vague images, such as the other group being rude, or does it focus on very specific behaviors, such as the Japanese always bow? Generally, more specific stereotypes are easier to deal with because exceptions are more easily noted and they can be considered in very concrete terms. Vague stereotypes, such as a group being rude, are difficult to deal with because what counts as rude can vary so much. Perhaps the volume of speech or the topic of a question is seen as rude in one group, but not in another, allowing one group to feel those other people are rude even when they have good will for that other group and the other group's behavior would be seen as appropriate within their own community.

\section{Consensus}

Consensus deals with how well accepted or well known certain stereotypes are within a community. Some stereotypes have become so well known that it only takes a very indirect reference to have them come to mind and virtually everyone you talk with has heard of them. In some cases, common stereotypes can become the basis for other stereotypes. For example, one woman who had been to Mexico to sell her handiwork at various craft fairs complained on her return to the U.S., "I guess they do make beautiful things, but I hate the way those Mexicans always Jew you down." In other cases stereotypes based on personal experience may really only be held by a particular individual or family group. Stereotypes that have wide consensus in a group may be easier to see exception in, but are often very hard to really get rid of even when they are obviously misleading and inaccurate.

\section{Accuracy}

Accuracy refers to how correct a stereotype is in describing the other group. One specific type of stereotype is called a sociotype, and from a statistical standpoint these are quite accurate. It may be discovered, for example, that a certain group 
has a particular average level of formal education or a certain average amount of income. Thus, someone may say that such and such a group is poor or wealthy and, in a group sense, this generalization is true. Also, because different cultural communities do share certain common practices and attitudes, other broad generalizations about the group as a whole may be fairly accurate. Of course, we realize that there are always exceptions and that even quite accurate stereotypes may mislead us in regards to a particular person. However, many stereotypes are not accurate even in a general statistical sense. In addition, very broad, abstract stereotypes, such as lazy, tight, rude, and dishonest, are particularly open to inaccuracies and misunderstanding of particular practices and different ways of interpreting the world.

Everyone stereotypes. We cannot help it. Cultural differences provide a fertile field for stereotypes because these differences call out for some explanation. This book and every book on intercultural communication or, for that matter, any book about people is full of stereotypes. Any idea that we are going to eliminate stereotyping is misdirected. We need categories to function in the world, and human categories unavoidably turn into stereotypes. What is important, then, is not eliminating stereotypes, but recognizing them for what they are and managing them in productive ways. This means working hard to make our stereotypes more accurate, keeping them open to being refined, and always allowing for individual differences. We hope that this book encourages that type of openness and accuracy. Periodically we have also tried to remind you that general statements made about a group will always have exceptions. This does not negate the value that understanding general cultural tendencies has, but it does warn against a sort of complacent acceptance and application of categories as we deal with others. Stereotypes are not inherently bad, but they are inherently dangerous and must be treated with conscious care.

If someone tells you that they don't stereotype people, it simply means they don't understand what a stereotype is or they are trying to cover up that they are stereotyping. Such a cover-up is likely due to the fact that stereotypes have come to be associated with negative images of the other group. Braaten reports on a multinational banking organization's internal survey that revealed many more negative stereotypes about members of other groups than positive ones even though management had thought the multiple cultural groups were getting along quite well. ${ }^{6}$ We will give you just a few of the examples: the Filipinos thought the Anglos were hypocritical and inconsiderate, the Anglos thought the Filipinos were petty and played favorites; the African Americans thought the Hispanics cocky and pushy and the Hispanics thought the African Americans too competitive and untrusting; the Afghans thought the Chinese did not really care about others, and the Chinese in turn thought the Afghans were bad. There were many more stereotypes reported and some were even positive, but the majority were negative. Does this mean that every group in the world is bad? No, but it 
is hard to find a very large group in which some people do not make foolish and sometimes bad choices. Using the reasoning of the fundamental attribution error, it is then quite easy to have "evidence" for negative stereotypes.

Reflection Question: Why are so many stereotypes negative?

In one of the classes we teach we have our students list on one day the different roles they play or groups to which they belong. The next day we put up one from each of their lists and ask the class in a general way to identify the stereotypes they are aware of regarding that role or group. There are consistently many more negative stereotypes than positive ones. Often these negative stereotypes are not so much based on wrong or bad choices by the other group, just different choices than we may be used to. If we remember that stereotypes are categories that grow out of our desire to understand differences that we perceive in others, this is not too surprising. Things that are different, unfamiliar, or unexpected tend to make us humans uncomfortable, and it is often easier to understand them in negative terms. However, there is another reason negative stereotypes seem so common. Although stereotypes are grounded in our human desire to understand the world, they can easily be tools in our efforts to build up our own group or community at the expense of others. Indeed, it is this destructive use of stereotypes that leads us into the next two concepts, ethnocentrism and prejudice.

\section{ETHNOCENTRISM}

Ethnocentrism has its roots in two words, ethno, or group, and centrism, or center, and it refers to assuming that one's group is the center of the world. In the original conceptualization of this concept, William Sumner went a step further and explained that ethnocentrism referred to the view that "one's own group is the center of everything, and all others are scaled and rated with reference to it." Thus, ethnocentrism is not just about one's own group, but about how other groups compare to it. Sumner also used the metaphor of war to explain how ethnocentrism functions. Herein lies a major difference between stereotyping and ethnocentrism. Stereotyping is grounded in an effort (albeit often flawed) to understand others, whereas ethnocentrism is grounded in competition and an often unconscious desire for victory.

Although ethnocentrism often deals with cultural differences, it is, in the final analysis, based on group membership and one's own group's relative standing among other groups. Therefore, it is always competitive, always centered around feelings of superiority over others because they don't "know" as much 
as us or don't do things the right way. Of course, the standard for this knowledge or "right" way is one's own group, so to whatever extent other groups vary from this standard, they are automatically wrong.

This does not mean that ethnocentrism is always obvious. For example, the United States may be the only country in the world where those involved in international business do not agree on the importance of fluency in a foreign language. ${ }^{8}$ Americans often argue that everyone speaks English and what makes a manager good in one place makes a good manager everywhere, and besides, you may wind up in different countries, so why waste your time learning a language you may not need? There is no doubt that English has become in many ways the global language of business and science, and this has certain advantages for bringing people together. At the same time it subtly creates many competitive advantages for those whose native language is English. Those who cannot speak fluent English or do not speak the "standard" dialect (meaning the dialect of those in power) of any language are often perceived and treated as somehow less intelligent than those who are fluent in English; such individuals are just as limited in their linguistic abilities and frequently even more so. ${ }^{9}$

Ethnocentric views are also expressed in the labels we have to refer to outsiders; for example, the implied evaluation in the terms Jew and Gentile. The Japanese refer to outsiders as gaijin. This term not only denotes outsider, but has a slight condescending and negative connotation to it. We hear the label foreigner often used in a slightly patronizing or negative way. When you hear the term barbarian, what does it bring to mind? Is it reliance on brute strength and uncivilized, uncouth manners and dress? The term has its origins in the Greek term barbarikos, and simply referred to anyone who did not speak Greek. ${ }^{10}$ It had nothing to do with table manners, level of civilization, strength, or anything else of that nature. It was, however, a term for outsiders that had negative connotations, and although many of the connotations have changed, they still tend to be negative.

Ethnocentrism has at times been associated with positive social outcomes. ${ }^{11}$ These include such things as a strong social identity, which may increase one's self-esteem, group loyalty, group survival, and the reduction of internal problems within a group. However, ethnocentrism also has many negative outcomes. It can prevent groups from learning new and productive knowledge that could be gained from other groups. In addition, feelings and expressions of ethnocentrism that protect a position of superiority breed increased competition, fear, anger, and hate, all of which can lead to different types of damaging conflicts.

Just as we all generalize our experiences with other groups of people through the process of categorization, thereby stereotyping them, we all carry the seeds of ethnocentrism with us as well. These seeds are our own cultural knowledge and lack of knowledge. The groups to which we belong and the ways of doing things shared by members of these groups are part of our cultural knowledge 
and serve as a point of reference for us to understand the world. This knowledge (of which stereotypes comprise one part) makes our social life possible. None of us is all-knowing; therefore, as we learn we typically do so by building on what knowledge we already have. If age is an important aspect of how we address other people, when we are trying to learn about how we should address members in another group we will be likely to ask questions related to how age impacts the way we should address others. It may turn out that age is not important at all in regards to personal address. Assuming that age is important may be termed by some as ethnocentric. It could also happen in reverse, such that someone from the group where age is not an important factor in addressing others doesn't even ask or worry about age when learning about address practices of the other group. Again, this person may be accused of ethnocentrism. However, we think these things are better viewed as ignorance, and we all have much about which we are culturally ignorant. Ethnocentrism sprouts from the seeds of cultural knowledge and ignorance that exist in all of us when we use this knowledge - or ignorance - to make evaluative judgments designed to demonstrate our superiority. If we decide that the other group is backward, uncivilized, thoughtless, or whatever because they either do or do not use age as a consideration in how to address others, thus demonstrating once again just how intelligent, caring, and wise our own group is, we might say that we are ethnocentric.

We are not trying to say that any evaluation of other practices is ethnocentric and should be avoided. These issues will be discussed more in Chapter 11, which deals with ethics. Taking an evaluative stance that group practices accepted by the Nazis in Germany were wrong is not what is being discussed as ethnocentrism. Ethnocentric evaluations are grounded in personal or group gain at the expense of others. However, sometimes these gains operate at an unconscious level, and it may be hard to see what type of plant our seeds of knowledge and ignorance are growing into. Charting ourselves on three continuums can help us be more aware when the weeds of ethnocentrism may be silently taking over our own personal gardens. ${ }^{12}$

\section{Concern/Indifference}

If we are sincerely concerned about others and their feelings and wellbeing, we are less inclined to be ethnocentric than if we are simply indifferent. One example of this that we have seen discussed throughout the United States is the issue of using names like Redskins, Braves, and Indians for professional sports teams. Not all Native Americans are concerned with this practice, but significant numbers are concerned with both the labels and the type of activities engaged in by some of these teams' fans. Perhaps your initial reaction is, "So what is the big deal? These names are traditional. People are supporting these groups, the labels are used to highlight positive competitive traits like strength and 
cunning, and besides, other groups are also labeled, for example, the Padres, Saints, and Vikings." These types of reactions all show a desire to justify what one group does at the expense of the other. No real concern for the Native American community is shown in these justifications. All of these justifications may be true, but it is also true that potentially damaging images are being perpetuated and large segments of the groups in question are hurt by the way these labels are used. Continued use of these labels in this way is clearly a sign of indifference. In a positive light, the University of Stanford did show concern in their name change a few years back, and also, from what we understand, the Seminoles as a tribe decided to support Florida State's use of the name Seminole. ${ }^{13}$ Both of these examples show concern rather than indifference because the community in question was listened to.

\section{Involvement/Avoidance}

As you observe or personally participate in decisions and judgments being made about another group, consider the amount of involvement with or avoidance of the other group. Ethnocentrism is often nurtured by avoidance. If we have minimal involvement with another group, it is very easy to be ethnocentric. We have seen professional groups organize to try to assist communities in need, yet only minimally consult with the community in question. It is just assumed that these professionals know what is best for the other group. They are then often surprised and even hurt when the group in question is not brimming with gratitude for all the help being given. These reactions can even promote more avoidance of the group and more ethnocentrism; after all, who wants to spend their time trying to help a group that just won't be helped? It is difficult to avoid ethnocentrism without extensive involvement.

\section{Enjoyment/Intolerance}

We may be both concerned about another group and involved, but if we are intolerant of differences, our efforts may simply be the ethnocentric desire to turn the other group into an exact copy of our own group. If we are intolerant of differences, we will always be fertile ground for ethnocentrism. We want to note that we purposefully avoided putting tolerance at one end of the continuum. We may tolerate differences, just as we tolerate some bothersome habit of a neighbor and avoid confronting our neighbor about it, but this does not mean we don't view ourselves and our ways of doing things as superior. It is only when we can honestly enjoy differences, even when they are not what we would personally choose to do, feel, or think, that we can avoid ethnocentric attitudes.

Thinking about the need to develop our enjoyment of differences, get involved with others, and be genuinely concerned about them, we suspect 
you can see how in an immediate sense it is much easier just act ethnocentric, just as it is easier to let your garden go to weed. Of course, the harvest is less than desirable.

A recent example of the competitive nature of ethnocentrism and how it can incorporate indifference, avoidance, and intolerance can be found in response to the Black Lives Matter movement. The Black Lives Matter campaign is not a single organized movement; rather it is an idea that has caught hold in a wide variety of places in the United States and around the world due to the shooting deaths of a number of black individuals in the U.S. Thus, the way the Black Lives Matter ideas are expressed can vary widely; however, the original ideas appear to us as an expression of concern over possible indifference and prejudice. Some have responded to this call with slogans such as All Lives Matter or Blue Lives Matter (referencing the police). There is nothing wrong with the message in these alternative expressions; surely all lives do matter. However, our observations suggest that many of these are presented in a competitive manner that competes with the original slogan, thus functioning to drown out the original idea and reinforcing the idea of indifference (and at times hostility) toward what was happening. These slogans can quickly become good points that are used to compete for very ethnocentric ideas in a political arena. We are reminded of an old joke whose punch line was something along the lines of "that was no lady, that was my wife." Obviously the person could be a lady and a wife. Bringing attention to the fact that we need to remember that Black Lives Matter when there has been concerns raised about this in no way suggests that other lives do not matter and does not need to be responded to as if it did.

Reflection Question: Ethnocentrism is sometimes linked to patriotism; is it possible to be patriotic without being ethnocentric? Explain your answer.

\section{PREJUDICE}

The nature of prejudice as it relates to intercultural communication and why we can't just all get along is more complex than is sometimes recognized and is more widespread than we wish to admit. In its broadest sense prejudice implies a judgment made in advance of some interaction. However, this definition is too broad to be of much use. There are countless definitions of prejudice in work on this topic. However, building upon points of agreement and in talking with many people about this topic, we define prejudice as a rigid attitude that is (1) based on group membership, and (2) predisposes an individual to feel, think, or act in a negative way toward another person or group of persons. ${ }^{14}$ 
Poor Tetsu. He's got no idea that people dislike him and don't want his taiyaki [sweet bread] because he's a cremator. He goes on thinking they'll sell if he makes them tastier. That's why he only uses good quality sugar, and the very best sesame-seed oil on the griddle to give a nice smell. But people don't realize that. They just go on talking about human oil and powdered bones, saying all sorts of unkind things. He can't win - they pick on him because his taiyaki are so delicious, but you can bet that if they were as tasteless and dirty as they usually are, they'd only say, "Well, what do you expect from a cremator?" Poor Tetsu, he's got no idea that people dislike him and don't want his taiyaki because he's a cremator ... ${ }^{15}$

This short excerpt from the novel River with No Bridge illustrates the major points of the definition of prejudice. First, the people's attitude referenced in the quote is resistant to change. It doesn't really matter how good or how bad Tetsu makes his bread; the people in question will always find a reason to be suspicious of it and dislike him. Second, the key to their dislike was not Tetsu the individual, but Tetsu the cremator. It was his group affiliation that triggered the reaction and was the basis for their suspicion and dislike. Group membership is always important in the way prejudice is defined here. It would be possible for someone to prejudge a proposal based on a series of personal experiences with the person making the proposal, but it would only be prejudice as defined here if it was also based in part on one of the person's group memberships. Finally, the presupposition the people in the excerpt had toward Tetsu because he was a cremator was negative. There is no positive prejudice. Their negative reaction did not necessitate dramatic confrontation; instead, the snubs were indicated to be so slight and subtle that Tetsu may not even have realized what was happening. Because prejudice is a presupposition to either act, think, or feel in a negative way it is not always obvious to those who are the target of the prejudice or to those observing from a distance that prejudice is being expressed.

This definition also highlights a number of differences between stereotypes and prejudice. Although stereotypes may be resistant to change, the intensity with which they are held can vary greatly. Prejudices are always rigidly held. Although stereotypes are never completely accurate, they can vary substantially in terms of accuracy. Not only are prejudices never accurate, they always distort one's vision in such a way that they always greatly warp our view of others. Stereotypes can also be both positive and negative, whereas prejudices are always negative. Stereotypes are based on categorizing and the human desire to make sense of our world. We have to be very careful how we use stereotypes, but when not focused on what is bad about another group, consciously left open to change, and relatively accurate in terms of general group tendencies, stereotypes can play a productive role in intercultural interactions. Prejudice is based on categorization and the desire to control others in ways that demean 
them directly or indirectly. Prejudice is never a productive part of intercultural relations. We can never really expect to rid ourselves of stereotypes, but we can hope to rid ourselves of prejudice. Finally, stereotyping is a practice, whereas prejudice is an attitude. Therefore, stereotypes can be a tool used by those who are prejudiced to control others.

Prejudice is much more closely allied to the competitive nature of ethnocentrism, but prejudice does not necessarily imply that one feels good about one's own group and group practices. We may feel prejudice against a group to which we belong. In addition, with prejudice the differences between groups are less concerned with differences in the way groups do things (like you often find with ethnocentrism), but with the sheer fact that it is a different group.

The definition of prejudice we are working with is also clearly tied to the concept of discrimination as it is used in the study of intercultural communication. Discrimination in this context occurs when prejudice is put into a tangible or concrete action. If a person uses his or her prejudice to make a decision related to who to hire or what person to vote for, then that person has engaged in discrimination. When people discuss discrimination in the workplace it tends to revolve around the use of factors others than individual merit to make decisions and is seen as a symptom of prejudice that is personally held or built into the structure of an organization. Repeated discrimination creates an environment of oppression that can at times be invisible to those who have become accustomed to the environment. For example, if group A was repeatedly denied educational opportunities and then tested in comparison to group B on set criteria that is typically taught as part of the educational experience, group A's lower score would not be a sign of less intelligence, but a sign of less opportunity. Yet it would be possible for members of both group A and B to say, "We gave them the same test. Group B must be smarter and, therefore, more deserving of increased educational opportunities."

It is also worthwhile to note that this definition of prejudice also recognizes that not all negative interactions involving people of various groups are an expression of prejudice. We may be intolerant, rude, or thoughtless to others based on general feelings of frustration or a personal grievance; however, this is not prejudice unless we have a negative predisposition toward other individuals based on their group membership. It is difficult with some outward actions to determine whether they are expressions of prejudice. In particular circumstances a person may say something rude or thoughtless to a good friend. People are not perfect, and it can be unproductive to assume too quickly that a negative action or comment is prejudice. This does not mean that prejudice is not a very real concern in the world today. Sometimes people subtly express prejudice without even realizing what they are doing.

To explain prejudice and to provide a foundation from which to defend ourselves from its negative influence, we will consider three different aspects 
related to it. First, we will review the general forms prejudice takes when it is being expressed. Second, we will examine the types of stories people tell themselves and others to account for prejudice in their own lives. Third, we will explore the functions of prejudice in terms of what people may be said to get out of it as well as the negative consequences for both the individual and society in general.

\section{Forms of Prejudice}

Prejudice is an attitude, which suggests that it occurs within a person. However, feelings of prejudice are such a large problem because they get expressed in a variety of ways, often without people even realizing or admitting to themselves that they are expressing prejudice. The following are descriptions of five common forms of prejudice. ${ }^{16}$

\section{Blatant}

Blatant prejudice is the active denigration of members of an outgroup. This type of prejudice is based on the belief that the outgroup is in some way inferior to the ingroup and, therefore, not worthy of decent treatment. The Ku Klux Klan has developed a reputation as an organization based on this form of prejudice. Manifestations of the prejudice include open statements about the inferiority of the other group, desires to have them go back to where they belong, or comments and thoughts about their innate dirtiness, laziness, and general backwardness. The outgroup is often treated and referred to as a type of pollutant. The idea of contact with members of this other group is generally repugnant. Some manifestations of blatant prejudice are quite violent, such as the physical beating or terrorizing of members of the hated group. As we write this there are a number of events in the news that provide examples of this, such as the burning of churches (many of them in black communities), the beating to death of a homosexual person, and a Swastika burnt onto the lawn of a Jewish family. Other blatant expressions are relatively peaceful, such as the decision not to hire someone based on their ethnicity, false claims that there are no vacancies at an apartment complex when the person is found to be of a different race, or comments made to a friend about how another group cannot be trusted because they are all liars. Blatant expressions of prejudice are what we typically think of when we think of prejudice. They are marked by a clear and open dislike for members of the other group.

There are a variety of efforts in the United States and other places that seek through education to stop such feelings and expressions of prejudice. It is easy to see that there are still many of these problems around us, but there is some 
evidence that formal education does help reduce the expression of this form of prejudice ${ }^{17}$ Alas, the same cannot be said for the other four forms of prejudice which in their own ways can be just as damaging, although more difficult to detect.

\section{Conceit}

As with blatant prejudice, conceit is marked by a sense that the other group is inferior to one's own. Manifestations of this prejudice tend to trivialize the other group. Thus, you find comments like, "She only got the job because she is black." This type of comment implies that the other group really isn't as good as the person's own group and so requires special privileges to make up for these incompetencies. This form of prejudice often involves making fun of the other group, its values, and ways of doing things. How often have you heard people sitting around telling jokes that involve negative depictions of another group? Do we join in with our own joke, just laugh in support of these kinds of put downs, or question this practice? When questioned about this type of prejudice people may respond, "What's the big deal? We're just having fun." Although the "fun" is neither violent nor as mean-spirited as one finds in blatant expressions of prejudice, it positions the other group as second-class and trivial. This sort of prejudice creates and reinforces expectations that members of the other group are lacking in terms of professional or social abilities.

\section{Symbolic}

Those who participate in symbolic prejudice will typically deny being prejudiced at all. Manifestations of this prejudice tend to be prominent in political spheres and can be found in statements that show antagonism toward the outgroup's actions in society ("Jews are getting too demanding"), resentment about so-called special treatment ("Why should Indians get rights that no one else does?"), and denial that prejudice is really a problem ("They have it too easy, and it is just breeding laziness"). Symbolic prejudice involves a concern for the status quo of existing power relationships and the fear that this other group is going to disturb it. Thus, only those who are in a position of power can engage in symbolic prejudice. This form of prejudice is also found in institutional practices that perpetuate certain advantages for the dominant group in a larger community. Often these advantages are difficult to see because we have become so used to them, such as the use of certain dialects as the "correct" way to speak or intelligence tests that use terminology that is culturally more familiar to certain groups of people. Education has much less impact on this and the other following forms of prejudice. 


\section{Tokenism}

Tokenism is usually found among people who know they harbor negative feelings about the other group, but do not like to admit that to either themselves or others. Essentially tokenism involves the giving of a token, or a relatively unimportant, but positive, item while withholding more substantial or significant assistance or involvement. The giving of the token is argued to be proof that the person is not prejudiced and allows the person to avoid engaging in more meaningful acts of equality. Thus, we may whip out a couple of dollars in support of some "needy" group, but we would never really want to spend time with people from this group. At an organizational level a company may include a token minority in their advertisements, but then enact a silent glass ceiling that would make it impossible for someone of an outgroup to be promoted into substantial leadership positions.

\section{Arm's Length}

Some people will engage in positive or friendly behaviors with members of the outgroup in one setting, but not in others. Thus, it may be fine to be friendly at work or school, but you would not want to socialize with them, live next to one, or have one as a close family member. In this way you keep members of this other group at arm's length. Sometimes this form of prejudice depends not so much on the physical setting, but on the relational setting, such that it is okay to visit with a person of this group if you are alone or with a few people you don't know that well, but if one's friends from within your own group are around, you ignore the other person or try to downplay any potential friendship. This is a difficult type of prejudice to detect because those who hold it can seem quite tolerant and open to outgroup members in certain settings.

In considering the various forms through which prejudice can be expressed, it is obvious that stereotypical, blatant acts of prejudice are only one part of the problem. Blatant acts of prejudice may get more attention because of their sensational nature, but the other, more subtle forms of prejudice are perhaps even more widespread and can be just as damaging for an individual or group.

\section{Rationalizing Narratives of Prejudice}

One of the intriguing things about prejudice is that, except for a few people who have become entrenched in blatant expressions of prejudice, virtually everyone acknowledges that it is both wrong and destructive. Yet, as we look closely, we are still surrounded by it and very likely find ourselves guilty of perpetuating it in some form or another. Why, one might wonder, don't we as individuals and 
as a group rise up and change this? In raising this question we are not denying that many good things are done in this area, but, given the amount of consensus concerning the negative nature of prejudice, it often seems to have the powers of the ancient serpent, Hydra, who grew two heads every time one of his heads was cut off. One way of better understanding this power is to look at the way people rationalize expressions of prejudice in their own lives.

The communication scholar Walter Fisher has argued that humans are essentially homo narrans, or storytellers, who implicitly or explicitly make sense of their world through narrative. ${ }^{18}$ Indeed, the quality of our lives is inseparable from the quality of our stories. In systematically analyzing 125 stories in which people talk about how they themselves have expressed prejudice as well as informally considering hundreds of others, we have found that there are basically five rationalizing narratives of prejudice that people use to make sense of prejudice in their own lives. ${ }^{19}$ These narratives may be entitled Morally Better, Personally Afflicted, Social Pressure, Their Turf, and System Abuse.

We will review each of these narratives in the following way. First, we will overview the general storyline told from the point of view of the person who has expressed the prejudice and focus on the types of characters involved, the problems they face, the actions they take in response to these problems, and expected outcomes. Then we will give two specific examples that are directly from stories we have analyzed to give you a better feel for this form of rationalization. Of course, each example has unique aspects, but they also follow the general storyline of the narrative type in question. Finally, we will briefly consider the rationalizing reason for the prejudice conveyed by each general story type.

\section{Morally Better}

\section{Story Line}

There is this group of people out there who think they're neat stuff, but if you objectively look at their actions and self-espoused attitudes, they actually are wrongheaded. Being an open sort of person, we don't like to make a big deal about it publicly. Generally we just avoid them, but when forced into contact we tolerate them as nicely as possible. However, when we are with our own group, who understand that we are good people, we speak condescendingly about them, and frequently we share a few jokes about them just for fun. Occasionally our own behavior toward this group surprises or embarrasses us, but truly it is the other group's own fault for not acting and talking appropriately in the first place. 


\section{Examples}

Prejudice is something that I pride myself on being aware of and avoiding. I try to see people as individuals and have found that there is always an exception to any stereotype. However, I found that there is a group of people with whom I have interacted that I hold a strong prejudice against. The intensity of my feelings surprised me... A particular incident of prejudice stands out in my mind because my feelings about it have not changed much. Several years ago I got involved with a Baptist church here in [town] because they offered sign language classes. I was just starting to take sign language classes at [the university] and wanted more practice and exposure to the language.

The group I got involved with also played volleyball as part of their parish activities. . They had what I considered were smarmy words and overly pious sayings on their shirts. The sayings were aggressive words and phrases that were turned around so that they were religious in nature. ... Throughout the tournament, I watched the young married men strut around with authority while their young, obedient, often pregnant, wives cared for their children... The roles of the women were that of demure, second-class people whose purpose seemed to be to gestate and care for children and to stand behind their husbands.

We were required to pray before and after everything that happened. The person who said the prayer would talk about God and people as if people were dirt. God was male and controlling. I stopped interacting with these people... I spent that tournament mentally making fun of the Baptists' ways and critiquing the things they value, such as men's dominant role. I considered their religion not as good as the one I was raised in and inferior to my current religious beliefs. My ideas of religion made them seem childish and backwards. . . The Baptists were claiming a "right" way of doing things and I felt great resentment about it. I will probably remain wary of this religion and the people that practice it even though I now understand why I felt such prejudice.

The other day my friends and I were talking outside a local bar downtown when one of our other friends, Marie, came by and introduced us to three guys. These guys had long hair, beards, and looked like they had not had a shower for about a week. She introduced them as some of her best friends. They were passing through town and staying at her house. The rest of my friends went back into the bar, but because Marie had to go get something I stayed and visited with them for a bit. I didn't want to be there. They talked about driving around from city to city playing their guitars on street corners to get money for food and gas. "Professional beggars," I thought.

When I finally got back into the bar with my friends we all started to joke about "Dead Heads" and "lost generation X." We made fun of their long hair. Later, Marie came in and invited us all to a dinner party at her house the next evening. Her "friends" would be there. I didn't say anything, but I didn't want 
to go. I am a pretty open guy about a lot of things and I don't want to be rude to others, but I didn't want any of their dirty hairs in my food just because they were too lazy to get a real job or clean themselves up. Besides, they seemed kind of gay and who knew what sort of disease they might be carrying.

\section{Rationalizing Reasons}

The reasons espoused in this type of narrative seem to take two sides of the same coin. On one side, the importance of maintaining appropriate behavior and beliefs and the other group's failure to do so is warrant enough for the expression of prejudice. On the other side is the sense that this is a choice and that the other group could be better if only they would. There is a strong sense of pride expressed in these stories.

There is one variation on the morally better stories that is worth noting here. It is when the person expressing the prejudice is also a member of the group that is being targeted for the negative feelings. The person doing this often feels they are being very objective about the whole situation, but actually they are following the same misguided reasoning as anyone else. These stories do, however, consistently include a different emotion in their telling, the feeling of embarrassment. For whatever reason they have come to accept the negative views of their group that are found around them. They are embarrassed by the negative connotations that then get attributed to them and tend to feel that they and perhaps a few others are "exceptions to the rule."

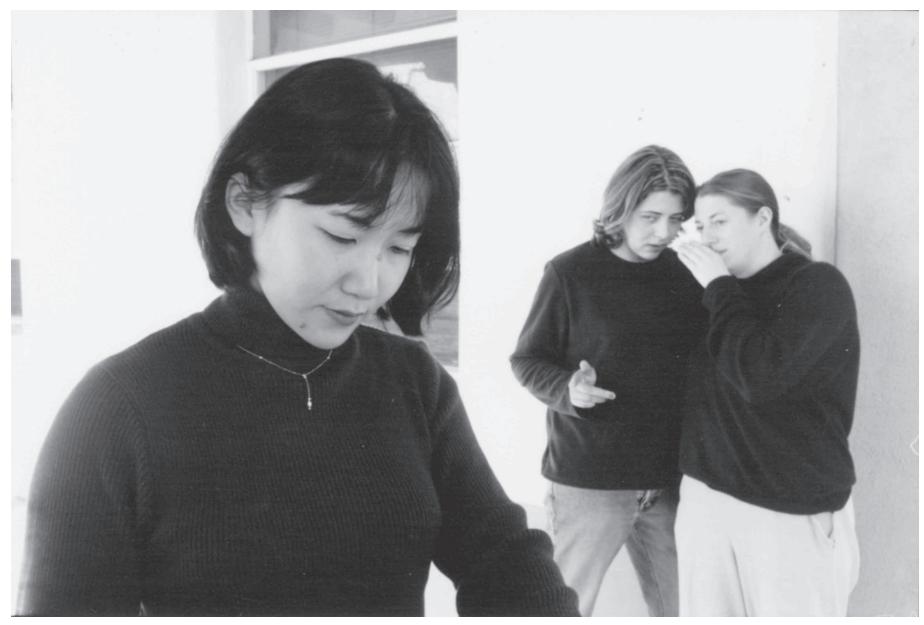

FICURE 7.2

Miguel Gandert 


\section{Personally Afflicted}

\section{Story Line}

Rationally we know prejudice is wrong, but in the past we or someone we loved was physically hurt or threatened by these slobs, so we can't help but feel the way we do. These people have proved themselves to be trouble starters, a threat to any peaceful and respectful society. Our past experience has caused us to fear, but mainly hate, this particular group. Generally we avoid them with a passion, but if they start anything, we hit right back vocally, physically, or any way we can.

\section{Examples}

When I was 18 I decided to go to our local junior college which was located in the city. While in high school, which was located only a mile away from the junior college, I was never exposed to the Asian population on a daily basis, but while in college I could not believe how many attended the school. Everywhere I looked there were Asians. I looked at them as I did anyone else, until I was put in a situation where I had to interact with them. One afternoon while on campus I entered a restroom alone, not noticing that I was the only white person, or what they would consider white, in the bathroom which was filled with five Asian girls. I call them Asian because I don't know whether they were Japanese, Chinese, or what. I did not think twice about being the only white person. It was not until they all began to talk in their own language, and not until they began looking and talking and laughing at me, that I finally realized I was the minority. As I went behind the stall, the talk became louder as did their laughs. As I approached the sink to wash my hands, the laughs and stares were so obviously directed at me that I became extremely uncomfortable. They just kept rambling on as they stared me up and down. My first thought was that these people have no manners as far as being considerate for other people's feelings. . . A feeling of rage came over me. I could not believe how rude these people were. From that point on I looked at every Asian person as rude and inconsiderate. . .

From that day on I have never been able to give an Asian person a fair chance to prove to me that they are not all like the girls who made fun of me. This particular incident left me with a negative feeling toward the whole Asian race. I know this incident may sound petty and insignificant to others, but it left me with a bad attitude toward the whole Asian population. This incident took place over ten years ago and I still remember it vividly.

I can remember as a child having to spend most of the day at a daycare center because both of my parents had to work. Due to the location of the school, I found that I was very much the minority with my lighter skin and blonde hair. One day I remember asking some older girls if I could play in the huge doll 
house with them. Their reply was that only girls with dark hair and dark skin were allowed in the doll house. I was very hurt and thought these Hispanic girls were very mean... When I was in sixth grade I had a bad run-in with the Mexican students known as Chicanos and Chicanas. For some reason that I did not understand I was beaten up. I was just a wimpy blonde who did not talk much unless it was necessary. I tried to stay clear from them, but the Hispanic girls wouldn't let me. In 7th grade I got to be so scared that my parents transferred me to a different school.

I recall even as a teenager walking in the mall and being called derogatory names by Hispanic teens. I was considered rich and preppy. I grew to despise the Hispanic culture. I considered them to be poor, rude, and downright uneducated. At the university I have met a lot of nice Hispanic people and I don't fear and hate them so much, but I still catch myself thinking bad thoughts about their culture and expecting them to cause problems.

\section{Rationalizing Reasons}

The most salient good reason in this narrative is that the narrator personally experienced the rottenness of the outgroup. A second good reason is that the narrator has experienced emotional injury as a result of the bad experience, and emotions are perceived as more powerful than rational thought. Thus, the narrator has a right to hate this other group.

\section{Social Pressure}

Story Line

I'm a liberal type of person with friends from many groups, including this particular outgroup. However, most, if not all, of our own group have a problem with this one outgroup. We don't want to rock the boat with our own group which we value very much, so we act in a way that denies or avoids any real or serious relationship with outgroup members. We feel really bad about this, but because our ingroup is so important to us, we don't see the situation improving anytime soon, if ever.

\section{Examples}

My most memorable experience with prejudice occurred when I was a junior at a suburban high school that had a relatively small number of blacks. Most students stayed away from the blacks, while a small percentage of the white 


\section{(continued)}

students befriended them and ignored the other prejudiced whites. I was one of those students who made friends with several black students. . There wasn't a prejudiced bone in my body, or so I thought.

There was a young black man named John who was a senior and in my creative writing class. I'd had classes with him before and I also sat at the same lunch table where he and his friends sat. We became good friends over a period of time until I received a note from him one day in class. It was a letter professing his true feelings for me. He wanted to know if I would be his girlfriend.

I didn't know what to do after I read the letter. I quickly left class when it was over. I hid out most of the day to avoid my friend. My lunch was spent in the girls' bathroom. When I arrived home that evening, the note accidentally fell out of my pocket and my mother found it. She knew who John was and what color he was and questioned me if I was seriously considering his offer. She told me that neither she nor my father would allow it and I would be thrown out of the house if I did see John on a serious relationship level.

I feigned illness the next day, but I did attend the day after and gave my answer to John. I lied by telling him I already had a boyfriend and he politely accepted my lame excuse. We both pretended like we could still be friends, even though we knew it wouldn't happen. . Things weren't the same between us after the incident. It was okay to socialize with John as a friend in school activities, but the thought of dating someone of a different race made me tense and nervous. This situation made me confront the fact that no matter how liberal everyone thought I was, I knew that I was prejudiced in my own way.

I don't like what happened with John. He was a very nice, sweet, and funny person and if he were white, I knew I would have gone out with him in a second. I honestly feel this incident isn't going to make things different the next time it happens. Regardless of where I'm living, I would still lose the respect of my parents and I don't want that to happen. My parents don't have me on a string, but they strongly influence me. There are a million men out in this world, but there's only one set of parents I have.

I can think of two experiences that I feel bad about, but doubt I would act any differently today. I worked at a nursery in Oregon that employed many Mexican nationals and I was friends with many of them. But our friendship did not always extend past the end of the workday. If I had invited my Mexican friends to my home for parties or down to the river for swimming and a cookout, I would have run the risk of alienating the friends in my group. So I didn't invite them, and avoided the sanctions of my friends. After I was married we moved to North Carolina. We developed some new friends named Bob and Betty. One time I remember we were in the backyard together, and we heard loud music coming from the yard down the block. 
Bob said, "It's probably the blacks, they don't have any respect for anyone else.

They turn their music up so loud that people five miles away could hear it."

I wanted to fit in so I said, "Yeah, no kidding."

\section{Rationalizing Reasons}

One reason for the expression of prejudice in this narrative is the fact that the person has had minimal or little contact with the other group while growing up. A second reason is that the narrator and the outgroup member are in fact different. The third and easily most pressing reason, however, is the importance of maintaining positive ingroup relations and the acceptance that a relationship with those from the outgroup will harm these ingroup relations.

\section{Their Turf}

\section{Story Line}

Actual contact with this other group is rather new to us. However, we have read and seen so much in the media about the crime and problems associated with this group that now that we are "closer" to them we are scared. They don't appear to respect the law like people we know. They all look the same and when we are on the street or some other unprotected area we fear what they may be plotting against us. We are so vulnerable. Therefore, during any interaction with them outside areas that we know to be safe or any time we are on their turf we try to do things as quickly as possible. It is too bad it has to be this way, but you never know what they might do.

\section{Examples}

I would say the strongest prejudice I have is toward black men. The reason this prejudice has developed is because I grew up in a small town with a very low percentage of blacks. Consequently I had very little interaction with them growing up. The exposure to blacks I had was through television programs and news stories. Granted the programs showed black men in both a favorable and unfavorable light, but they are seen as villains more often than good guys. That combined with watching news and seeing how much crime and violence is related to black men caused a prejudice based on fear to develop within me. 


\section{(continued)}

When I first moved to [this town] I was exposed to blacks and their culture for the first time and, although I hate to admit it, fear was there. I had stereotyped their race as being bad. . .

I have lived [here] for four years and I had hoped I would get used to seeing the basketball players that live here. I haven't. When I pass them, especially if it is a group of them, I am on my guard and somewhat afraid. I think part of it has to do with the fact that I am a small, white female and that I am in one of the most, if not the most, vulnerable groups in society in terms of violent crime.

For example, in a previous job, sometimes black men would come into the center for services. I treated them in a friendly manner, but if I see them socially, I am much more distant. At work, it is a safe situation. I am behind a desk, with many people around and there is knowledge that chances are real good nothing will occur. In that situation, I feel they are on my "turf" and, therefore, play by those rules. In a social scene that is not so and it scares me. . .

I have lumped black men into one category - that of violence, crime, bad attitudes, and the like. I realize it is wrong, but again, it is based on a very strong fear that realistically I will never get over. Actually, I hope I do not get over it because I do not want to let my guard down. I do not want to be any more vulnerable than I already feel I am.

I come from a town that has only about a 5 percent minority population. It was quite a shock to see so many Asians and black people all over the place. After some time in the city I developed a close friendship with a person from work named Pam who was of black heritage. We spent a lot of time together inside and outside of work, but it didn't change my fear of blacks. One time I was walking in downtown, when a black man yelled my name and started running after me. I began to walk much faster and tried to ignore him. He finally caught up to me and tapped me on the shoulder and I turned around scared to death, when I realized it was Pam's husband. He only wanted to ask if I needed a ride somewhere. I told him he scared me to death and he apologized. He thought I would recognize him and seemed a bit embarrassed. We all laugh about it now, but it was uncomfortable because even though I trust Pam and her husband I know I really don't trust other black people, especially when I am just out on the street.

\section{Rationalizing Reasons}

The objective sense of many media reports provides justification for the expressions of prejudice in this narrative. This is especially powerful when combined with the personal feeling of vulnerability. Finally, lack of experience is also seen as a warrant for this expression of prejudice. 


\section{System Abuse}

\section{Story Line}

We are normal, competent, hardworking people and it really bothers us to see people getting unfair advantage in the system due to some accident of birth. This injustice of getting rewards based on group membership not merit makes it tough for people like us who earn our rewards to get what we actually deserve. We are, therefore, understandably angry and when talking within our own group we often refer to the outgroup in derogatory terms and tell stories of how they perpetuate injustice. We wish we could get rid of Affirmative Action and other quota systems and just concentrate on real merit. But, given the political problems of the day, it is unlikely.

\section{Examples}

I work in a bank with about 50 people with a very even distribution of black and white employees. My account has to do with my superior who is black. She is viewed by many as incompetent. To clarify, I am not saying she is incompetent because she is black. The perception I usually have is that she was given the job because she's black and the corporation had to fill a quota of minority managers. At least once a week there is a comment made regarding why she was given that job, because she is basically unskilled in management. As a result, there is a lack of respect for my superior and we make fun of the way she speaks. . .

For a time I worked outside the United States as a machinist and high-pressure welder. When I returned to the U.S. I had trouble finding a job and was always being turned down for one reason or another. Because of this I began to feel that I was being discriminated against because I am a minority. I was upset and couldn't understand how people could do this. I felt I was shielded from ever discriminating against others because of my minority status. I will explain how I found out that was not true. Deciding that eating had become a priority I swallowed my pride and found myself standing in the line at the local welfare office. I explained my situation, but because of my previous year's earnings I only qualified for 14 dollars in food stamps. Some reward for working, I thought.

Anyway, my next stop was the grocery store. I very carefully picked out 14 dollars' worth of goods and went to the shortest line. They were all quite busy because it was a government payday. An Indian woman and her three children beat me to the line. It was still the shortest line so I stayed there. The Indian woman's basket was to the point of overflowing and she struggled to push it. As the clerk began to ring up the items she turned in my direction and began to speak in an Indian dialect. At first I thought she was talking to me, but then 


\section{(continued)}

I saw an Indian man pushing one and pulling another grocery cart, both of which were overflowing.

I then heard her say in bad English, "That is my husband and we are paying with a government WIC check." This is one of the few checks issued by the Federal Government where the purchase amount is filled in by the store clerk (a blank check!?!). The clerk then asked me to let the husband through.

I couldn't believe it. I stopped short of making a scene, all the while thinking to myself, "These damn Indians have it made, no wonder I'm only getting 14 dollars. "I felt the Indians were being allowed to corrupt an already unjust welfare system. After I quickly got through the line with my little amount, I saw the same Indian family loading their groceries in a brand new Chevy Van. I was fit to be tied! I couldn't wait to get with my friends and tell them about these Indians who were drunk most of the time, who cheated the rest of us out of our rights by taking advantage of the system.

\section{Rationalizing Reasons}

The major good reason espoused in these narratives is that the outgroup is unfairly taking advantage of the system. A secondary reason cited is the loss of opportunities for the storyteller and others like him or her because of the behavior of the outgroup.

Table 7.1 provides an overview of the rationalizing narratives of prejudice. We do not believe that the people who tell these rationalizing narratives are abnormal or inherently bad. They have chosen ways of viewing and coping with a challenging world that will be damaging to themselves and others, but they can learn to make better choices. The label of prejudice is a very damaging label in today's world, and people create life stories that make prejudice both sensible and acceptable in their specific case, while at the same time allowing them to condemn it in a general sense. This type of rationalization makes it hard to overcome prejudice. No one wants to be stigmatized as prejudiced; therefore, we tell stories to ourselves and others that prevent us from recognizing bad choices and working on making better ones.

The point here is similar to the "difference between saying 'Arthur lied to me last Tuesday,' and saying, 'Arthur is a liar." ${ }^{20}$ We may all have lied at some point in our lives, but does that make each of us a liar? A person who cannot be trusted? The traditional ways in which prejudice is often treated and taught push people into an all-or-nothing or "liar" type of category, thus ignoring the possibility that prejudice is not so much an essential part of what a person is as a context-specific choice. It is easier for a person to make changes in something 
TABLE 7.1 | Overview of rationalizing narratives of prejudice

\begin{tabular}{|c|c|c|c|c|c|}
\hline & $\begin{array}{l}\text { Morally } \\
\text { Better }\end{array}$ & $\begin{array}{l}\text { Personally } \\
\text { Afflicted }\end{array}$ & $\begin{array}{l}\text { Social } \\
\text { Pressure }\end{array}$ & Their Turf & System Abuse \\
\hline $\begin{array}{l}\text { Dominant } \\
\text { Emotion }\end{array}$ & Pride & Hate & Resignation & Fear & Anger \\
\hline Narrator & $\begin{array}{l}\text { Objective, } \\
\text { Open, \& } \\
\text { Principled }\end{array}$ & $\begin{array}{l}\text { Innocent } \\
\text { Victim }\end{array}$ & $\begin{array}{l}\text { Strongly } \\
\text { Attached } \\
\text { to Own } \\
\text { Group }\end{array}$ & $\begin{array}{l}\text { Vulnerable \& } \\
\text { Inexperi- } \\
\text { enced }\end{array}$ & $\begin{array}{c}\text { Hard-working \& } \\
\text { Fair-minded }\end{array}$ \\
\hline The "Other" & $\begin{array}{c}\text { Choosing } \\
\text { Wrong }\end{array}$ & $\begin{array}{l}\text { Mean } \\
\text { Trouble- } \\
\text { Starter }\end{array}$ & $\begin{array}{l}\text { Nice, but } \\
\text { Different }\end{array}$ & $\begin{array}{c}\text { Dangerous, } \\
\text { Criminal }\end{array}$ & Free-loader \\
\hline $\begin{array}{l}\text { Major } \\
\text { Source }\end{array}$ & $\begin{array}{l}\text { They } \\
\text { Violate a } \\
\text { Perceived } \\
\text { Universal } \\
\text { Principle }\end{array}$ & $\begin{array}{l}\text { Personal } \\
\text { Experience }\end{array}$ & $\begin{array}{l}\text { Family \& } \\
\text { Friends }\end{array}$ & Media & $\begin{array}{l}\text { Personal } \\
\text { Observation } \\
\text { \& Stories }\end{array}$ \\
\hline $\begin{array}{l}\text { Expression } \\
\text { of Prejudice }\end{array}$ & $\begin{array}{l}\text { Avoid \& } \\
\text { Joke } \\
\text { About } \\
\text { Other }\end{array}$ & $\begin{array}{l}\text { Avoid \& "Hit } \\
\text { Back" }\end{array}$ & Avoid \& Lie & $\begin{array}{l}\text { Avoid \& } \\
\text { Watch } \\
\text { Carefully }\end{array}$ & $\begin{array}{l}\text { Avoid \& } \\
\quad \text { Complain }\end{array}$ \\
\hline
\end{tabular}

they do than something they are. Although this is only a subtle change in perspective, it can be very enlightening and empowering as we discover prejudice in our own lives and the lives of others.

Reflection Question: Prejudice is grounded in an emotional reaction and cannot just be gotten rid of by simply being told that it is not a good idea. What are some ways you would suggest that a person could get rid of prejudice in his or her own life?

\section{Functions of Prejudice}

Even though we understand the many ways prejudice may be expressed and how people are able to justify its occurrence in their own lives, we may still wonder why anyone would engage in it in the first place and why it appears to be such a universally prevalent problem. ${ }^{21}$ Much like certain addictive drugs, prejudice appears to help us deal with certain challenges while simultaneously creating greater problems in the future. We will review five of the functions or transitory "helps" that prejudices seem to hold for us when we feel and express them. ${ }^{22}$ 


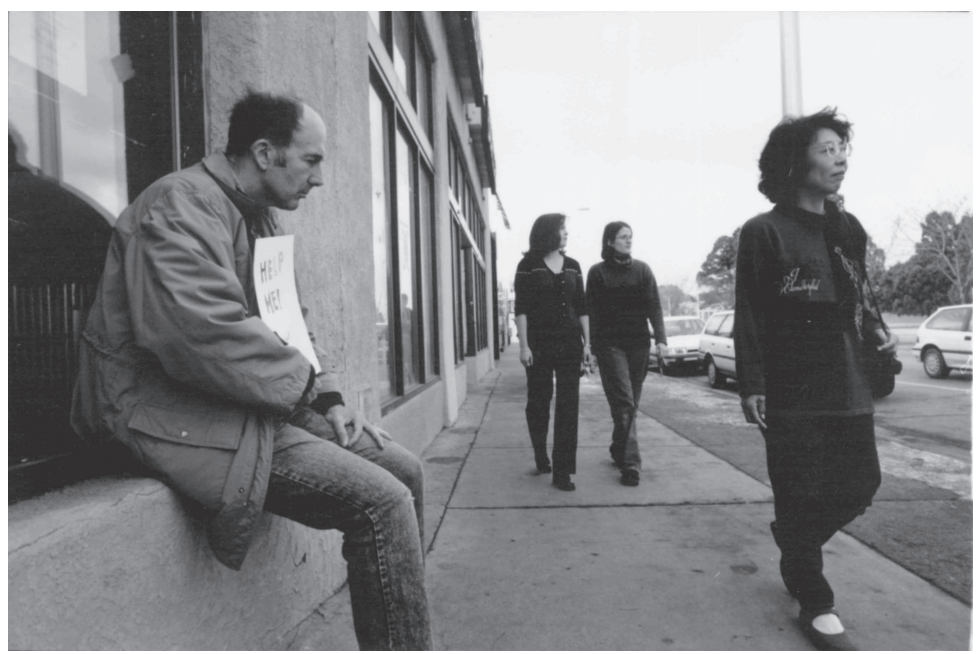

FIGURE 7.3

Miguel Gandert

\section{Utilitarian}

One reason that people hold prejudice is that it is rewarded in tangible and monetary ways. If jobs are scarce, prejudice may be a way to reduce competition for those jobs and, consequently, the valued resources they entail. Prejudice that is held by those in economically powerful positions can channel certain groups of people into socially undesirable jobs (economically and physically). Prejudice provides a justification for occupational decisions that maintain or establish certain economic advantages and disadvantages. This function seemed to be a prime motivator in much of the West Germans' feelings of prejudice in regards to the East Germans after the two countries were unified. ${ }^{23}$ Finally, prejudice may help certain social groups maintain political power in spite of an apparently fair political system.

\section{Social Status}

The social status function also contains a type of reward, albeit less tangible. Prejudice may boost one's standing within one's own community or at the very least help one avoid social sanctions from those of the ingroup. One certainly does not want to be viewed as fraternizing with the enemy when there are obvious tensions between communities. In addition, when prejudice is being expressed it takes people who are very secure with themselves to take the social risk of naming it for what it is and encouraging others to give it up. Thus, for 
an English person to joke about the Irish or a French person to joke about the Belgians and Belgians to joke about the Dutch and Spanish people to make fun of the Basque are ways in which people establish themselves as right within their own community. For many people, their expressions of prejudice are simply a way of trying to build themselves up or maintain a desired social position.

\section{Ego-Defensive}

In the ego-defensive case prejudice allows people to avoid admitting certain things about themselves. If one has been unsuccessful in any kind of endeavor, blaming that lack of success on those of an outgroup can protect one's own self-esteem. If we can believe that the only reason another person got a promotion is because they are of a "privileged, but unworthy" group, we do not have to face any potential personal inadequacies. Thus, for a short time, prejudice can help people feel better about themselves. This is a common function of prejudices found within the workplace.

\section{Value-Expressive}

Prejudices can be held because they allow people to highlight certain aspects of life that they highly prize. These aspects might include basic values concerning religion, government, aesthetics, or relationships. One Japanese American student shared with me how her mother frequently taught her how to act appropriately by referring in prejudicial ways to other Asian groups. For example, her mom would say, "I never want to see you sitting like that! Only Vietnamese do that!" and the student would know what her mom meant and find it unacceptable as well. She believed that her mom did this in part to counteract the lumping of all Asians together into one big group. The United States and Poland are hardly countries that could be said to be in competition with each other or who have a relationship that would need clarifying, yet Polish jokes are common in the United States. Through the use of the negative, these jokes seem to highlight culturally important attributes. Prejudice thus ironically becomes a way to celebrate the "good" and for a person to show that he or she knows who he or she is and supports what is right.

\section{Easy Knowledge}

Prejudice also allows people to organize and structure their world in ways that make sense and are relatively convenient. Prejudice allows a person to avoid dealing with individuals on an individual level, thus making many social decisions quick and easy. Based on the other's group membership, one knows whether or not to interact with that person and how to approach that interaction 
if it should occur. Archie Bunker became a popular culture celebrity based on his readily organized, prejudicial view of the world. He knew immediately who was worth talking to or who to trust just by the person's group membership. Of course, problems occur because easy knowledge often proves to be faulty.

Hopefully the last two sections on rationalizing narratives and the functions of prejudice are useful in helping us to see how and why prejudice can creep into all of our lives even when we know it is destructive. Let us think about some of these less-than-desirable consequences as they relate to each of the five functions reviewed previously. At the same time that the utilitarian function economically rewards certain groups, it prevents others from receiving appropriately deserved rewards. It reminds me in principle of part of the problem with shoplifting. A shoplifter may justify his or her actions based on the idea that big stores have plenty of money and so they won't miss little items. These items add up, however, and the stores then raise prices to cover these losses, causing problems for everyone, especially those who are simply working hard to earn their paychecks and don't take advantage of anyone. Prejudice is always felt and affects someone in a negative way, even when one small act is not noticed immediately. In addition, as our society tries to be fair and deal with the effects of prejudice, laws and programs are put in place to correct these problems. Some of these programs create their own difficulties, but as long as we have prejudices directed at utilitarian benefits we will need these other compensating programs and laws. As with so many things, prejudice is a vicious cycle.

The social status, ego-defensive, and value-expressive functions are all similar in that these apparently good things (social acceptance, self-esteem, and strong values) are all built on a faulty foundation that is always under threat of crumbling. When we try to build these good things through expressions of prejudice, we try to establish our own success on the failure of others. The idea that for us to succeed others must fail is a popular misconception in the world today. This form of thinking in everyday life creates a defensive atmosphere in which persons from all groups involved have to expend considerable amounts of energy just protecting themselves. There are better ways to build positive social acceptance, self-esteem, and value adherence than through the tearing down of others. Some of these issues will be revisited in the next two chapters which deal with conflict.

Finally, easy knowledge is also a misleading function, because the type of knowledge we have is always a distortion of the way things either are or can be. Many opportunities for personal growth, solving problems, and developing uplifting relationships are lost through assumptions about other people that limit contact with them and prevent us from seeing new information that could help us in our daily lives. Although prejudice may make some decisions convenient, it does not mean that those decisions are the best ones, and the effort expended 
at maintaining the walls of prejudice is often more draining than just letting go of the prejudices we have. Just as our children will sometimes work incredibly hard and for many minutes to avoid doing a five-minute job, we lose more through protecting prejudice in our own life than we ever gain.

\section{SUMMARY}

In response to the question of why we can't just all get along, the answers of stereotyping, ethnocentrism, and prejudice cannot be avoided. These three concepts can be seen throughout the world and until we can understand them and deal with them in our own lives, we will always be left wondering why we all can't just get along.

We began this chapter by examining how stereotypes are a natural part of our social world. Humans need to categorize to deal with the world around them and as we categorize people, generalizing certain traits to groups of people, we stereotype. Stereotyping is a way we try to learn about our world, but unless we are very careful it can end up distorting our perceptions of the world. Stereotypes are often negative. The fundamental attribution error was discussed as representing the basic thought process that underlies much of our stereotyping. We learned that stereotypes can vary along certain dimensions such as direction, intensity, specificity, consensus, and accuracy.

After considering stereotypes, we learned about ethnocentrism. Ethnocentrism occurs when we treat our group as the center of all that is right and judge others accordingly. Of course, we all understand the world from our own limited experience and knowledge, but such understanding becomes ethnocentric when an element of competition is included. We may not always recognize our own ethnocentrism in our quest for success in life. It is often reflected in the language we speak. Ethnocentrism is especially likely when we are indifferent to others' concerns, avoid interacting with others, and find ourselves intolerant of differences.

Finally, the concept of prejudice was defined as a rigid attitude that is (1) based on group membership, and (2) predisposes an individual to feel, think, or act in a negative way toward another person or group of persons. This definition allowed us to see many different forms through which prejudice could be expressed as well as recognize that not every negative intergroup interaction is an example of prejudice. We considered some of the rationalizing narratives people tell themselves to justify prejudice in their own lives. We also reviewed five functions of prejudice. These functions may seem like benefits, but when examined more closely damaging consequences both for individuals and whole communities are revealed. Prejudice is a problem each of us can work on in our own lives. 


\section{REFLECTION QUESTIONS}

1 Are stereotypes harmless or dangerous? Explain your answer. What impact do stereotypes have in your life?

2 Can we eliminate ethnocentrism in our own lives? How? Or why not?

3 A variety of forms of prejudice were covered in this chapter; can you think of any other forms not covered? Give specific examples.

4 Do you recognize any of the rationalizing narratives in your own life and in the lives of those around you? How could you change these narratives so as to avoid the negative impacts of prejudice in your own life?

\section{ACTIVITIES}

1 Imagine you have a car to sell. How would you approach selling it differently (what features highlighted, etc.) to an older gentleman, a mother with young children, a female college student, a teenage boy? How does this relate to stereotyping? Or role-play in class how you would greet a potential business client who is from Japan, Saudi Arabia, New York, California, Mexico, and so forth. How does this relate to stereotyping?

2 Select groups from around your campus, athletes, engineer majors, communication majors, art majors, fraternity and sorority members, international teaching assistants, professors, campus police, financial aid officers, and so forth. Brainstorm in a group all of the stereotypes of which you are aware related to this group. What do they tell you about the group? What sort of consequences do these stereotypes have on these people?

3 Draw a map of the world with as much detail (countries named) as possible. How well do you know where other countries are? Where is your home country placed on the page? Near the center? Ask others to do the same exercise. Do they also place their own country in the center? How does this exercise illustrate ethnocentrism?

4 Take one minute and try to list as many American heroes or important public leaders as you can. The leaders or heroes can be from any area of public life and can either be alive or dead. Now take a minute and list as many African American heroes or public leaders you can. Next list as many Native American heroes or public leaders as you can in a minute. Then do the same with Jewish Americans. Next see how many heroes or public leaders you can remember in a minute from the Hispanic/Chicano/Mexican American community. Finally, how many Asian American heroes or public leaders can you list in a minute? Now examine your lists and consider how they may relate to ethnocentrism. Does your first list have a lot of white males? Does your African American heroes list include a lot more sports 
figures than the other lists? Does your Native American list include a lot of dead chiefs? Why are we aware of some of these people and not others? Do some groups just have fewer heroes and leaders?

5 Examine the rationalizing narratives of prejudice provided in the chapter. What forms and functions can you see displayed in these stories? What examples of prejudice can you find in popular culture? Discuss and compare your findings with others.

6 Write an essay about a time when you expressed prejudice, either through thoughts, feelings, or actions. Consider it in terms of the narrative types discussed in this chapter and the forms and functions of prejudice. Consider what changes you have made or would like to make in the future in reference to this prejudice.

\section{NOTES}

1 N. Cantor, W. Mischel, and J. Schwartz, "Social Knowledge," in Cognitive Social Psychology, ed. A. H. Hastorf and A. M. Isen (New York: Elsevier/North-Holland, 1982), 33-72.

2 L. Ross, "The Intuitive Psychologist and His Shortcoming: Distortions in the Attribution Process," in Advances in Experimental Social Psychology, Vol. 10, ed.

L. Berkowitz (New York: Academic Press, 1977), 174-220; and T. F. Pettigrew, "The Ultimate Attribution Error: Extending Allport's Cognitive Analysis of Prejudice," Personality and Social Psychology Bulletin 5 (1979): 461-76.

3 B. Davies and R. Harré, "Positioning: The Discursive Production of Selves," Journal for the Theory of Social Behavior 20 (1990): 43-63; and B. R. Schlenker, Impression Management (Monterey, CA: Brooks/Cole, 1980).

4 Based on V. Vassilou, H. Triandis, G. Vassilou, and H. McGuire, "Interpersonal Contact and Stereotyping," in The Analysis of Subjective Culture, ed. H. Triandis (New York: John Wiley \& Sons, 1972).

5 A. Tan, "The Language of Discretion," in Language Awareness, 6th ed., ed. P. Eschholz, A. Rosa, and V. Clark (New York: St. Martins Press, 1994), 352-9.

6 D. O. Braaten, "Banking on Diversity: Familiarity Breeds Contempt at Security First Bank," in International Business Case Studies, ed. R. Moran, D. O. Braaten, and J. Walsh, Jr. (Houston: Gulf, 1994), 347-63.

7 W. G. Sumner, Folkways (New York: Ginn, 1906), 13.

8 I. Varner and L. Beamer, Intercultural Communication in the Global Workplace (Boston, MA: Irwin/McGraw-Hill, 1995).

9 For a full discussion of these matters, see Y. Tsuda, Language Inequality and Distortion in Intercultural Communication: A Critical Theory Approach (Amsterdam, the Netherlands: John Benjamins Publishing Company, 1986).

10 W. B. Gudykunst and Y. Y. Kim, Communicating with Strangers: An Approach to Intercultural Communication, 3rd ed. (New York: McGraw-Hill, 1997); see also F. C. Mish, Webster's Word Histories (Springfield, MA: Merriam-Webster, 1989).

11 Gudykunst and Kim, Communicating with Strangers; and R. Brislin, Understanding Culture's Influence on Behavior (Fort Worth, TX: Harcourt Brace Jovanovich, 1993).

12 J. Lukens, "Ethnocentric Speech," Ethnic Groups 2 (1982): 35-53. 
13 Brad confirmed this by calling the Seminole tribal office. He was told that the tribal chairman, James Billie, had publicly stated that he was proud to have Florida State use the tribal name. This is a very different situation than those where the Native Americans want the name changed. Each should be respected.

14 J. Duckitt, The Social Psychology of Prejudice (New York: Praeger, 1992); G. W. Allport, The Nature of Prejudice (Reading, MA: Addison-Wesley, 1954); and G. Simpson and J. M. Yinger, Racial and Cultural Minorities, 5th ed. (New York: Plenum Press, 1985).

15 S. Sumii, River with No Bridge, trans. S. Wilkinson (Rutland, VT: Charles E. Tuttle, 1990), 272.

16 Adapted from work by R. Brislin, "Prejudice in Intercultural Communication," in Intercultural Communication: A Reader, 6th ed., ed. L. Samovar and R. E. Porter (Belmont, CA: Wadsworth, 1991), 364-70.

17 Brislin, "Prejudice."

18 W. Fisher, "Narration as a Human Communication Paradigm: The Case of Public Moral Argument," Communication Monographs, 51 (1984): 1-22.

19 All of the material on rationalizing narratives of prejudice including the table is derived from B. J. Hall, "Narratives of Prejudice," Howard Journal of Communications 9 (1998): 137-56.

20 J. C. Condon, Semantics and Communication, 3rd ed. (New York: Macmillan, 1985), 78.

21 Duckitt, Psychology of Prejudice.

22 Adapted from work by D. Katz, "The Functional Approach to the Study of Attitudes," Public Opinion Quarterly 24 (1960): 164-204; J. Levin, The Functions of Prejudice (New York: Harper, 1975); and R. Brislin, "Prejudice in Intercultural Communication," in Intercultural Communication: A Reader, 4th ed., ed. L. Samovar and R. E. Porter (Belmont, CA: Wadsworth, 1985), 366-71.

23 G. Nees, Germany: Unraveling an Enigma (Yarmouth, ME: Intercultural Press, 1999). 